\title{
On the Chinese Complex in My Several Worlds: A Personal Record*
}

\author{
Ruihong Peng \\ Shandong Jianzhu University, Jinan, China
}

\begin{abstract}
Pearl S. Buck' description on the Republic of China in the 1930s based on her own life experiences in Anhui province and Jiangsu province has created for it a complex but unique image which has been controversial since its birth. Her inclusive and understanding attitude toward cultural exchange between China and the west is very worthy of advocating. Pearl S. Buck was always inclined to her "second motherland", and took Chinese and Western folk cultural exchanges as her noble mission. She had a quite strong attachment to China in her whole life, while the West misunderstood and excluded Chinese culture, and there were major obstacles to cultural exchanges. Therefore, Pearl Buck and her works were misunderstood and criticized by Chinese readers in a quite long historical period, sharply contrasting her lifelong love for China and her tremendous contributions to the Chinese people. In the global context, we have studied Pearl Buck again, with a view to cherishing her friendship with Chinese people and emphasizing her unique cultural value and practical significance to China.
\end{abstract}

Index Terms - China complex, Pear Buck, My Several Worlds: A Personal Record

\section{INTRODUCTION}

Pearl Buck was born on June 26, 1892 in West Virginia, USA, and then she was put in the cradle and drifted across the sea to China with her parents after three months of her birth, and lived there for 40 years. Based on her life experiences in China and Chinese culture attainment, she broke the limits of the understanding of the West on China and observed China and the world from the point view of Chinese people.. That is why her works accurately reflected the Chinese people's psychology, aspirations, feelings and emotions and what Chinese people really looked like. Pearl Buck sympathetically portrayed diligent and down-to-earth Chinese farmers and vividly pictured their family life in her works by using straightforward writing skills. Characters in her works are vivid and full of true feelings, and scenes and details are true and credible.

Her works transcended the gap between Chinese and western cultures, and uncovered the mysteries of China for western readers, effectively changing the image of "Chinese pagans" and "mysterious China" depicted by many western writers.

Pearl Buck completed her first autobiography in the United States, My Several worlds: A personal Record, which was published in 1954 and focused on her life experiences in China, but also talked about her experiences in the United States, Japan and other countries. In the book she recounted the historical realities of China history, her growth and simple but honest ties with lower classes. Although she pointed out the inadequacies of China, but her deep love for China was throughout the book.

\section{THE RESEARCHES ON PEARL S. Buck}

Pearl Buck had been in an intercultural and bilingual environment since childhood. It is no exaggeration to say that her knowledge, creative inspiration and successful career benefitted from her life experiences in China. As an American who lived in China for a long time, Pearl Buck recorded a unique China in English from her own perspective, creating a distinct image of China and setting a successful example for colliding and blending of Chinese and Western cultures. She used to being anxious about her contradictory identities, and tried her best to figure out where she belonged culturally. In fact, her anxiety stemmed from the conflict of different cultures. Therefore, she always regarded herself as a cultural practitioner who transcended Chinese and Western cultures, and considered the promotion of mutual understanding and exchanges between the Chinese people and the western people as her lofty mission. She was highly praised for this, and also received a lot of criticism and opposition.

Research on Pearl Buck in China used to attract much attention. Many translators were devoted to translating Pearl Buck's works after they were published. They also became the first critics of Pearl Buck's literary works. Consequently, most researches were based on text analysis. Most comments on Pearl Buck's literary at that time discussed whether Buck Pearl reflected China's true situation for the Western world or not.

\footnotetext{
* This work is one of the results of Program "Research on Missionaries in Modern China and Shandong Education" (16DJYJ01) with the support of Humanity and Social Science Youth Foundation of Shandong Province of China in 2016.
} 
Lin Yutang (1999) highly praised Pearl Buck in The Great of Mrs. Buck: "I found that Mrs. Buck was a master writer but a brave and calm critic who boldly criticized preachers in China. It was more important that she criticized the Chinese nation, giving a sharp warning to Chinese people in higher social classes and patriots". (p.109) Zhuang Xin (1999) gave Pearl Buck a more objective evaluation in his article Mrs. Buck and Her Works: "At least Mrs. Buck introduced the reality of China to the West in a sincere and objective manner in spite of some exaggeration and distortion. Chinese people should be grateful for that in the process of national rejuvenation" (p.22) However, not all of translators gave their full affirmation to Pearl Buck's works. In a personal letter to Yao Ke, Lu Xun (1999) said: "What is China really looks like depends on what Chinese people write. Mrs. Buck used to be popular in Shanghai, and she also called China as her mother land. However, her works told us that she was just a female priest living in China.” (p.3)

Considering Pearl Buck's research was associated with China-U.S. relations, it had gone to extremes after 1949 as China closed the door to outsiders and the Cold War began.

World Literature and Literature Review published in succession two review articles in 1960, Xu Yuxin's Pearl Buck: A Pioneer Of The Cultural Aggression Of The American Imperialism and Li Wenjun's An Analysis On The Chinese Pearl Buck Made By The United States, which strongly criticized Pearl Buck. Literary researchers had set out to pay attention to Pearl Buck since 1980s, a bridge for friendly cultural exchanges between China and the West, as the Cold War ended, China and the United States established a friendly diplomatic relationship and China launched the reform and opening up. Translations of Pearl Buck's works reached a high record in the 1990s. Seminars on Pearl Buck and her works appeared in China as a number of translation versions were published. More and more objective evaluations on Pearl Buck have been made in the literary circles from then on. In addition, many scholars have studied Pearl Buck from various perspectives such as feminism, Chinese-Western cultural exchanges, cultural studies, comparative literature imagery, and post-colonialism. We have found that Pearl Buck's research was no longer confined to a single field in the new century, and more researchers performed their study from interdisciplinary and cross-cultural points, comprehensively improving the recognition and evaluation on Pearl Buck's historical status.

Most international findings on Pearl Buck focused on writing biographies for her, research papers and monographs. Peter J. Conn gave an objective on Pearl Buck in Pearl S. Buck: A Cultural Biography, stating that Pearl Buck was imprinted with two cultures and had a deep desire to promote the cultural integration between China and the West. Robert Spino in his The American Literature History made a brief introduction to Pearl Buck, a Nobel laureate. The History of Columbia Literature, edited by Amery Elliot, used only two sentences to introduce Pearl Buck. All above have proved that Pearl Buck was not accepted and recognized by the mainstream academic communities of the United States. Sergei Yeva in her paper, said: "However, Pearl Buck attempted to erase huge changes that were taking place in Chinese politics and society, which is a great flaw of her works." (Yeva, 1999, p.576)

Liao Kang in his book, Pearl S. Buck-A Cultural Bridge Across The Pacific Ocean, adopted the acceptance theory to explain why Pearl Buck's works were popular, and gave political reasons that Pearl Buck was criticized and neglected. He also highly praised her outstanding contributions to the cultural exchanges between China and the West, and explored the role of Pearl Buck in transforming the traditional understanding of the West on the image of China.

\section{PeARl S. BucK’S “PARTIALITY” Under DuAl Education}

Growing up in a bilingual environment, Pearl Buck has a strong feeling for China and the Chinese people. She once said: "My life, from a child to a young girl and then to an adult, belonged to China."(Shang Yinglin \& Zhang Zhiqiang, 1991, p.10) She learned Chinese first, and then English. She was able to speak and write in both languages at the age of 4. Pearl Buck read a large number of Chinese classical novels and modern works when she was a teacher in Nanjing Jinling University in 1921-1934, giving her deeper understanding on Chinese psychology.

Pearl Buck later recalled: "I grew up in a double world, the small white clean Presbyterian American world of my parents and the big loving merry not-too-clean Chinese world, and there was no communication between them. When I Was in the Chinese world I was Chinese, I spoke Chinese and behaved as a Chinese and ate as the Chinese did, and I shared their thoughts and feelings. I am familiar with every inch of land, like familiar with the wrinkles on my face..." (Buck, 1954, p.10) The Chinese Revolution of 1911 and the May 4th Movement broke out as Pearl Buck was a teenager. Such an unusual social change and cultural trend had implications on her. She thought that the Chinese New Culture Movement created "a new force for modern China" and would release "the energy that had been suppressed for many centuries". She obtained a unique perspective reflecting and analyzing China's issues earlier as she knew Chinese and Chinese classical literature very well and maintained frequent contacts with many people who participated in the Chinese New Culture Movement.

Pearl Buck liked to hear stories from others when she was young. She learned Chinese culture in China's old-style private school. Therefore, she not only mastered Chinese, but also had a sound understanding of China's history, culture and literature. Pearl Buck took nutrients from Chinese literary works and historical culture, and had a deeper understanding on the folk customs of the ancient oriental country. She made extensive contacts with farmers. Visiting farmers had become her only way to find the real life. That helped her to accumulate a great amount of materials about village life. She found the purest feelings of mankind among those farmers, and felt their diligence, kindness, and cleverness as well as their optimistic attitude toward natural and man-made disasters. That gave her impulse to write down her indignation for Chinese farmers and the common people she beloved. 
Peal Buck began her writing career at the time of the Chinese New Culture Movement. She was very excited at the moment. "It was the best time for me to live in China, and I was young and interested in all things around me. I mastered English and Chinese...." (Buck, 1954, p.138). Pearl Buck was gradually integrated into the academic community after a dozen years of living in Nanjing. China's literary movement was subject to the revolutionary culture at home and abroad and developed. All above contributed to Pearl Buck' knowledge accumulation for creation. It is very clear for us to find that Pearl Buck used many writing skills and inspirations from Chinese classical novels and traditional art of storytelling in her works.

In The Good Earth, we can see that she adopted the descriptive approaches of Chinese folk storytellers; In The Pavilion of Women, we can clearly feel the influence of A Dream of Red Mansions on her writing skills and narrative style; In A House Divide, we can see that she was inspired by the plot description of the peasant uprising in The Water Margin. Pearl Buck published a total of 116 literary works in her whole life, most of which were completed in the United States but derived materials from the East, especially China. They analyzed China issues in a deeper way. "I grew up in a double world, the small white clean Presbyterian American world of my parents and the big loving merry not-too-clean Chinese world, and there was no communication between them. When I Was in the Chinese world I was Chinese, I spoke Chinese and behaved as a Chinese and ate as the Chinese did, and I shared their thoughts and feelings. When I was in the American world, I shut the door between." (Buck, 1954, p.10) Georg Simmer, a famous German sociologist, had given a definition to "stranger" that "the stranger is not the wanderer who comes today and leaves tomorrow, or may be called a potential wanderer, though he has not gone, he has not forgotten the freedom of coming and going."(Simmer, 1991, p.131-37)

From a sociological point of view, Pearl Buck lived in China as a "stranger" all along even though she regarded China as her second homeland. Pearl Buck lived in China for nearly forty years. She had her own life, with Chinese dishes as her favorite. In her pictures she always wore Chinese-style clothes. She could speak Chinese as fluently as Chinese did. She attended classes with Chinese teachers. She was fond of Chinese stories. She had deeper understanding and study on Chinese culture. It seemed that Pearl Buck was a Chinese. It is due to her life experiences in China that she developed the same emotions as Chinese people.

However, Pearl Buck's high nose, blue eyes, and fluency in English told Chinese around her that she was a "stranger" who came from a different race and spoke English. Her race and American-style values she received from her mother determined that she was a "stranger". What is puzzling is that she was still an "stranger" after she returned in the United States. The key reason to that is that Pearl Buck went to China with her parents since childhood and grew up in China. To a certain extent, that helped her to be integrated into China, an oriental country quite different from the United States. Such identity as a "stranger" affected her whole life no matter which country, China or the United States, she lived in.

Pearl Buck, as a double "stranger" who lived in the East and the West for a long time, lived in the country that was quite different from the United States both in living habits and historical and cultural backgrounds, and that was new and hard to understand for her and her family. It is due to her mother, Kelly, that the United States was not at all far away from the heart of young Pearl Buck though she lived in China. Her mother described the United States as a nearly ideal country, which inspired the longing of young Pearl Buck to return to the United States. Such longing became stronger when she witnessed the Chinese society suffered so many disasters. She had a higher sense of superiority on the American culture and society. That means she still had the qualities of the western people in her inner world. In fact, Pearl Buck' inner world is involved in two heterogeneous cultures, the Chinese culture and the western culture. However, her works show what she chose and absorbed from two cultures rather than her ambiguity rising from them.

Her unique life experiences had not made her truly see into both societies of China and the United States. However, it was such life experiences that enriched her cultural backgrounds and inner world, and shaped her unique and glamorous personality as well as a distinct mental world where Chinese culture and western culture were fused together.

\section{Pearl S. Buck And Chinese Culture}

The traditional concepts of Western Christianity and Chinese Confucianism had main effect on Pearl Buck's cultural thoughts. The collision and integration of Christianity and Confucian thoughts laid the foundation for her thoughts in terms of her family atmosphere and the social environment. Pearl Buck was born in a missionary family. His father worked tirelessly to spread the gospel of God in his whole life. How he treated others and how he behaved were deeply imprinted in the young Pearl Buck's heart. His father was devoted to advocate helping the poor and the weak and pursuing loftiness, equality, fraternity and inclusiveness. Pearl Buck thought what her father advocating stood for the essentials of Christianity.

The ethics-based Confucian culture dominated the Chinese traditional culture. Pearl Buck once said: "Confucius developed my thoughts, behaviours, and personalities when I was young. Confucianism is my reference standard.” This stemmed from the social and family environment where she grew up. She had been in China for the first dozens of years of her life when her views on world and life were formed. In addition, Pearl Buck was educated in the old-style private school. Her enlightenment teacher was typical of Confucian scholars.. That means that her living environment and education backgrounds imprinted her with the Confucianism, which produced inexhaustible energy for her in the rest of her life. 
She had appreciated and respected Chinese culture in her whole life. In My Several Worlds: A Personal Record, she wrote: " It seems that Chinese people will have the wisdom passed down from one generation to another and a natural philosophy once they was born. They are so wise that you will get incisive and humorous philosophies even if you talk with illiterate farmers." Confucianism advocates that brothers do not only refer to those who have blood relation, but also to friends who resonate with each other in spirit, can share weal and woe and make progress together. Such a peaceful and beautiful human relations maps had generated an irresistible charm for a white young girl who lived abroad. The Confucian quote, "All men are brothers" became her creed. When she introduced China to the West, she did not choose the intellectuals who belonged to the higher social class and paid no attention to social issues but focused on ordinary but great people who vigorously lived at the bottom of the society and "fight against natural and man-made disasters "as they are brave, generous, polite, kind, wise and happy though they are illiterate, live in a simple but rough life and are separated from modern thoughts and technology."

Acquired cultivation makes people different even if there is no obvious difference of natural qualities. The Chinese saying, "All men are brothers", dose not include the mob but noble persons who understand each other very well. Pearl Buck built her own spiritual building under the guidance of Confucianism. She practiced her contemporary religious views which were combined with humanistic care of Confucianism. Pearl Buck maintained a close relationship with China and Chinese culture. She had made outstanding contributions to the cultural exchanges between East and West, especially to cultural exchanges between China and the West. President Nixon called her as "a bridge between the civilizations of East and West".

Pearl Buck did what she advocated in real life and did concrete things for two-way cultural exchanges between the East and the West. She founded the East-West Exchange Society in 1941, and found some Asians and asked them to show what they really were and introduced their history and civilization. At the same year, Pearl Buck took over the magazine, "Asia", which played an immeasurable role in solving the Far East issue. It was the pioneer who published the world-well known reportage, "Red Star Over China”, which was written by Edgar Snow after his trip to Yan'an. And then the reportage had its separate version. Edgar Snow's another work, "Autobiography of Mao Zedong, was first published by Asia, too. Nehru, Lu Xun, Mao Zedong, Tagore, Soong Ching Ling, and Hu Shi wrote articles for it. Pearl Buck endured great hardships in pioneer work of cross-cultural exchanges and worked hard to promote exchange, complementation and fusion of heterogeneous cultures. She hoped that the Eastern and Western cultures would respect each other, seek common ground while reserving differences, and oppose cultural imperialism. She struggled to establish a multicultural identity with a view to promoting cross-cultural exchange and transmission.

Yan Lipeng in his dissertation said that Pearl Buck lived in China about for half a lifetime, and she had an inextricable Chinese complex. She was full of sympathy and love for Chinese farmers, strongly recommended and actively disseminated Chinese traditional culture. Therefore, Pearl Buck is a friend of the Chinese nation and Chinese people. It is worth of our commemoration and study. In addition, it is very clear for us that Pearl S. Buck grew up in China and had special feelings for Chinese culture and Chinese people. For example, Pearl Buck described in The Earth many rural customs in China from the view of Chinese in a detailed and accurate way. She expressed her sympathy and compassion to farmers. Her novels, to some extent, corrected the early stereotypes of American people about China and deepened their impressions on China. However, Pearl Buck failed to truly reflect the social reality of China in the early 20th century and China's national liberation war. That is because her potential readership was the American public, who knew little about Chinese culture. She would lose a part of readership if she represented social conditions of China truly and accurately. Pearl Buck deliberately simplified the description of Chinese culture and diluted the social and political background of China for the sake of comprehensibility and readability of her novels. Pearl Buck used her artistic approaches rather than realistic techniques to integrate her Chinese materials into her novels with a universal theme, which was conducive to her novels' spread in different cultures. (cf. Yan Lipeng, 2017, abstract)

Besides, we can perceive that there was misunderstanding and exclusion between East and West in the age when Pearl Buck lived, and there were major obstacles to cultural exchanges in the true sense. Therefore, Pearl Buck and her works were misunderstood and ignored by Chinese readers for quite a long historical period, sharply contrasting with her lifelong love for China and her tremendous contributions to the Chinese people. However, more and more researchers have changed their focus to Pearl Buck and her works in China today. In the global context, we have studied Pearl Buck again, with a view to cherishing her friendship with and emphasizing her unique cultural value and practical significance to China..

\section{REFERENCES}

[1] Buck, Pearl. (1954). My Several Worlds: A Personal Record. New York: John Day.

[2] Lin Yutang. (1999). "The Great of Mrs. Buck". Guo Yingjian Edited. Pearl S. Buck Collection. Lijiang: Lijiang Publishing House.

[3] Lu Xun. (1999). “To Yao Ke”. Guo Yingjian Edited. Pearl S. Buck Collection. Lijiang: Lijiang Publishing House.

[4] Shang Yinglin \& Zhang Zhiqiang trans. (1991). Pearl: My Chinese world. Changsha: Hunan Literature and Art Publishing House.

[5] Simmer, Georg. (1999). General Information, Cheng Boqing Trans. Hangzhou: HangZhou University Press.

[6] Yan Lipeng. (2017). Pearl S. Buck's Understanding and Misinterpretation of Chinese Culture in The Good Earth. Shanghai International Studies University. 
[7] Yeva. (1999). "China Hand Bankruptcy-Pearl S. Buck”. Guo Yingjian Edited. Pearl S. Buck Collection. Lijiang: Lijiang Publishing House.

[8] Zhuang Xin. (1999). "Mrs. Buck and her Works". Guo Yingjian Edited. Pearl S. Buck Collection. Lijiang: Lijiang Publishing House.

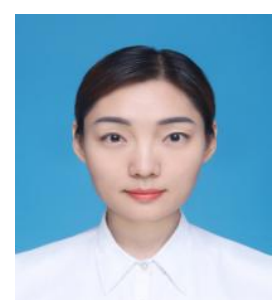

Ruihong Peng was born in Shandong, China in 1982. She graduated from Shandong University with a Bachelor's degree in English major. She got the Master of Arts in Education in Shandong Normal University. She is currently studying in Shandong University for a Doctor's degree in literature.

She is now working as a teacher in School of Foreign Languages of Shandong Jianzhu University in China. She has been teaching English for 15 years. The following is one of her publications:

Peng R. (2011). a study on English program for postgraduates in universities of technology from the CBI perspective. Journal of Jilin Engineering Normal University. 2016.12, 7-9.

She is interested in sinology, English teaching and studies. Her Program "Research on Missionaries in Modern China and Shandong Education" (16DJYJ01) has won the support of Humanity and Social Science Youth Foundation of Shandong Province of China in 2016. 